\title{
Interactions of Cadmium(II) and protons with \\ dead biomass of marine algae Fucus sp.
}

\author{
R. Herrero, B. Cordero, P. Lodeiro, C. Rey-Castro, M.E. Sastre de Vicente* \\ Departamento de Química Física e Enxeñería Química I, University of A Coruña, \\ Alejandro de la Sota, 1, 15071 A Coruña, Spain. \\ *Corresponding author e-mail address: eman@udc.es; fax: +34 981167065.
}

\begin{abstract}
Samples of dead biomass from the marine brown algae Fucus ceranoides, F. vesiculosus and F.serratus were studied for their ability to remove cadmium from aqueous solutions. The metal sorption process is rapid, with $90 \%$ of the metal uptake completed within the first 25 min. of contact. The kinetic data was described successfully by a pseudo second order chemical sorption process with rate constants of ca. $0.6 \mathrm{~g} \cdot \mathrm{mmol}^{-1} \cdot \mathrm{min}^{-1}$. At $\mathrm{pH} 4.5$, the raw biomass of the three species exhibited equilibrium uptake capacities for $\mathrm{Cd}$ as high as $0.8 \mathrm{mmol} \cdot \mathrm{g}^{-1}\left(90 \mathrm{mg} \cdot \mathrm{g}^{-1}\right)$, on a dry weight basis, without chemical pretreatment. These sorption capacities are much higher than those reported for activated carbon and chitin. The sorption of Cd was found to increase as $\mathrm{pH}$ increases, reaching a plateau at $\mathrm{pH} 5$.

Batch sorption experiments and continuous potentiometric titrations of acidtreated biomass samples in $0.05 \mathrm{M} \mathrm{NaNO}$ 3ere used to derive thermodynamic binding parameters according to the NICCA model. The total amount of acid sites was 2.4-2.9 $\mathrm{mmol} \cdot \mathrm{g}^{-1}$, with median values of the affinity distribution for protons and cadmium ions, $\log \widetilde{\mathrm{K}}_{\mathrm{H}}$ and $\log \widetilde{\mathrm{K}}_{\mathrm{Cd}}$, of 3.7 and 2.69 respectively (conditional values). The apparent heterogeneity of the sorbent was successfully taken into account by the empirical
\end{abstract}


NICCA isotherm, which described very well the competition between protons and metal ions, in contrast with a simpler discrete competitive Langmuir model.

The experimental results demonstrate that these seaweeds constitute a promising, efficient, cheap and biodegradable sorbent biomaterial for cadmium removal from wastewaters. This use would represent an example of exploitation of a renewable marine resource in water treatment technologies for the prevention of heavy metal pollution in the environment.

Keywords: biosorption; wastewater treatment; heavy metals; marine algae; potentiometric titration; voltammetry.

\section{Introduction}

Pollution by metal ions is one of the major environmental problems in many countries because the contents of metal ions in potable waters and wastewaters in many cases exceed the admissible sanitary standards.

Aqueous effluents emanating from many industries contain dissolved heavy metals. If these discharges are emitted without treatment, they may have and adverse impact on the environment. Cadmium is one of the heavy metals with a greatest potential hazard to humans and the environment. Cadmium poses a serious threat to human health as it accumulates on the environment throughout the food chain. Besides, the industrial uses of cadmium are widespread and increasing in electroplating, paint pigments, plastics, alloy preparation, mining and silver-cadmium batteries (Wase and Forster, 1997).

Higher awareness of the ecological effects of toxic metals and their accumulation through food chains has prompted a demand for purification of industrial 
wastewaters prior to their discharge into the natural water bodies and increasing interest has been shown in the removal of heavy metals. Conventional methods for removing metals from industrial waste solutions, such as chemical precipitation, filtration, ion exchange, electrochemical treatment or membrane technology, may be ineffective or extremely expensive, especially when the metals are dissolved in large volumes of solution, at relatively low concentrations.

The use of inexpensive biological materials, such as bacteria, fungi and algae, for removing and recovering heavy metals from contaminated industrial effluents has emerged as a potential alternative method to conventional techniques (Kapoor and Viraraghavan, 1995; Volesky, 2001).

Basically, biosorption can be based on the following mechanisms: physical adsorption, ion exchange, complexation and precipitation. Biosorption may not necessarily consist of a single mechanism. In many sorption processes more than one of these mechanisms take place and it is difficult to distinguish between the single steps (Lacher and Smith, 2002).

Many types of biomass have been reported to have high uptake capacities for heavy metals, including cadmium. Among these materials, some species of brown marine macroalgae exhibit much higher uptake values than other types of biomass, higher than activated carbon and comparable to those of synthetic ion exchange resins. This is the case of different species of Fucus, which constitute a renewable, ubiquitous natural marine resource, available in large quantities in littoral zones and therefore, an inexpensive sorbent material.

The algal cell wall of marine algae contains a high proportion of alginate constituting $14-40 \%$ of the dry weight of the biomass. Alginic acid is a polymer composed of unbranched chains of 1,4-linked $\beta$-D-mannuronic and $\alpha$-L-guluronic acids 
(Percival and McDowell, 1967). Other negatively charged functional groups, such as the sulphonate groups of fucoidan, also contribute to heavy metal complexation although it is difficult to evaluate the absolute role that these polymers play in determining the heavy metal uptake.

The present work reports a study of the cadmium adsorption by non-living biomass of several types of Fucus sp. originated from the Galician coast (NW, Spain), where they are very abundant often posing environmental nuisance. The biosorption process has been analyzed through batch experiments at $25^{\circ} \mathrm{C}$ with regard to the influence of initial metal concentration and $\mathrm{pH}$ on both the raw and protonated biomass. Also the acid-base properties of these algae have been studied as they are related to their capacity of binding to metals. Finally, a complexation model for cadmium sorption on Fucus sp. has been developed in order to explain the adsorption behaviour.

\section{Experimental}

Samples of marine algae Fucus serratus, Fucus vesiculosus and Fucus ceranoides were collected from A Coruña coast (Galicia, Spain). They were washed twice with running water and once with deionized water. After drying at $60{ }^{\circ} \mathrm{C}$ for 24 hours, they were crushed and ground in an analytical mill (IKA A 10) to granules of 0.5-1 mm. This material will be referred to as raw biomass.

The chemicals used in this work were $\mathrm{HNO}_{3}$ (Merck suprapur and Merck pro analysis), $\mathrm{NaNO}_{3}$ (Merck pro analysis), $\mathrm{Cd}\left(\mathrm{NO}_{3}\right)_{2} \cdot 4 \mathrm{H}_{2} \mathrm{O}$ (Merck pro analysis), $\mathrm{NaOH}$ (Merck pro analysis), $\mathrm{HCl}$ (Merck pro analysis), $\mathrm{N}_{2}$ from Carburos Metalicos and cellulose nitrate membrane filters (Whatman and Albet). Samples of the algal raw biomass were acid-treated with diluted $\mathrm{HCl}$ following the procedure described 
elsewhere (Rey-Castro et al., 2003), in order to transform the biomass into its fully protonated form (acid-treated biomass).

\subsection{Kinetics of cadmium biosorption}

Kinetic experiments were performed by adding $0.25 \mathrm{~g}$ of algae to $100 \mathrm{~mL}$ of cadmium solution $\left(2.22 \mathrm{mmol} \cdot \mathrm{L}^{-1}\right)$ at constant temperature $\left(25.0 \pm 0.1{ }^{\circ} \mathrm{C}\right)$. The ionic strength was adjusted to $0.05 \mathrm{M}$ with $\mathrm{NaNO}_{3}$. The cadmium concentration in the aqueous phase as a function of contact time was monitorized by means of a cadmium ion selective electrode (Cd-ISE) previously calibrated in cadmium concentration at 0.05M ionic strength.

The cadmium uptake at each moment is calculated from the equation:

$$
\mathrm{q}_{\mathrm{Cd}, \mathrm{t}}=\frac{\mathrm{V} \cdot\left(\mathrm{c}_{\mathrm{Cd}, \mathrm{i}}-\mathrm{c}_{\mathrm{Cd}, \mathrm{t}}\right)}{\mathrm{m}_{\mathrm{s}}}
$$

where $\mathrm{V}$ is the volume of cadmium solution, $\mathrm{c}_{\mathrm{Cd}, \mathrm{i}}$ is the initial cadmium concentration, $\mathrm{c}_{\mathrm{Cd}, \mathrm{t}}$ is the concentration of cadmium in solution at a given time, and $\mathrm{m}_{\mathrm{s}}$ is the mass of sorbent on a dry weight basis.

\subsection{Sorption of cadmium at equilibrium}

For Cd sorption equilibrium studies, eight cadmium solutions with concentrations ranging from 0.089 to $3.11 \mathrm{mmol} \cdot \mathrm{L}^{-1}$ were prepared by dissolving $\mathrm{Cd}\left(\mathrm{NO}_{3}\right)_{2} \cdot 4 \mathrm{H}_{2} \mathrm{O}$ in deionized water or $\mathrm{NaNO}_{3}$ aqueous solutions of $0.05 \mathrm{M}$ overall ionic strength. The experiments were performed in $100 \mathrm{~mL}$ conical flasks containing $0.1 \mathrm{~g}$ of algae (raw or acid-treated biomass) and $40 \mathrm{~mL}$ of cadmium solution. The mixtures were agitated on a rotary shaker at $175 \mathrm{rpm}$ for 3 hours. $\mathrm{NaOH}$ and $\mathrm{HNO}_{3}$ were used for $\mathrm{pH}$ adjustment. The algae biomass was filtered through a $0.45 \mu \mathrm{m}$ pore size cellulose nitrate membrane filter and the concentration of cadmium in the filtrates was determined by 
differential pulse anodic stripping voltammetry (DPASV) by use of 757 VA Computrace (Metrohm) with a conventional system of three electrodes: hanging mercury drop electrode as working electrode, Pt auxiliary electrode and Ag/AgCl (3 M $\mathrm{KCl})$ reference electrode. Adsorption isotherms were achieved at $\mathrm{pH} 4.5 \pm 0.1$ for all algae (raw biomass) and at $\mathrm{pH}$ values of $6,4.5$ and $3( \pm 0.1)$ for acid-treated samples of F. serratus. The effect of $\mathrm{pH}$ on cadmium uptake has also been studied.

The amount of cadmium sorbed at equilibrium, $\mathrm{Q}_{\mathrm{Cd}}$, which represents the metal uptake, was calculated from the difference in metal concentration in the aqueous phase before and after adsorption, according to the following equation:

$$
\mathrm{Q}_{\mathrm{Cd}}=\frac{\mathrm{V} \cdot\left(\mathrm{c}_{\mathrm{Cd}, \mathrm{i}}-\mathrm{c}_{\mathrm{Cd}}\right)}{\mathrm{m}_{\mathrm{s}}}
$$

where now $\mathrm{c}_{\mathrm{Cd}}$ is the equilibrium concentration of cadmium in solution. This equation is formally identical to Eq. (1), but referred to the equilibrium concentration. Note the capital letter used to distinguish between the equilibrium sorption, $\mathrm{Q}_{\mathrm{Cd}}$, and the timedependent uptake, $\mathrm{q}_{\mathrm{Cd}, \mathrm{t}}$.

\subsection{Potentiometric titrations of biomass}

The proton binding equilibria were studied through potentiometric titration of the acid-treated biomass using glass electrodes (GK2401C Radiometer). For this purpose, ca. $0.5 \mathrm{~g}$ of protonated algal biomass were placed in a thermostated cell at $25.0 \pm 0.1{ }^{\circ} \mathrm{C}$, under nitrogen stream, and $100 \mathrm{~mL}$ of $0.05 \mathrm{M} \mathrm{NaNO}_{3}$ solution were added to keep ionic strength constant. The suspension was titrated with a $0.05 \mathrm{M} \mathrm{NaOH}$ standard solution delivered from a Crison microBu 2031 automatic burette. The procedure followed for the titrations and glass electrode calibrations was described in greater detail elsewhere (Rey-Castro et al., 2003). 
The amount of proton bound is calculated from the acid and base additions by means of charge balance considerations:

$$
\mathrm{Q}_{\mathrm{H}}=\mathrm{Q}_{\text {max }, \mathrm{H}}-\frac{\mathrm{V}_{\mathrm{T}}}{\mathrm{m}_{\mathrm{s}}}\left(\left[\mathrm{H}^{+}\right]+\frac{\mathrm{V}_{\mathrm{b}} \mathrm{C}_{\mathrm{b}}-\mathrm{V}_{\mathrm{a}} \mathrm{C}_{\mathrm{a}}}{\mathrm{V}_{\mathrm{T}}}-\frac{\mathrm{K}_{\mathrm{w}}}{\left[\mathrm{H}^{+}\right]}\right)
$$

where $\mathrm{V}_{\mathrm{i}}, \mathrm{C}_{\mathrm{i}}$ are the volume and concentration of the acid and base added (subscripts a and $\mathrm{b}$ refer to acid and base, respectively), $\mathrm{V}_{\mathrm{T}}$ is the total volume in the titration vessel, $\mathrm{K}_{\mathrm{W}}$ is the ionic product of water, and $\mathrm{Q}_{\mathrm{max}, \mathrm{H}}$ is the total amount of titratable groups, calculated from the equivalence point of the titrations.

In addition, $0.25 \mathrm{~g}$ of $F$. serratus were suspended in $100 \mathrm{~mL}$ of an aqueous solution of $2.22 \mathrm{mmol} \cdot \mathrm{L}^{-1}$ of cadmium at an ionic strength of $0.05 \mathrm{M}$ (adjusted with $\mathrm{NaNO}_{3}$ ) and titrated against $0.05 \mathrm{M} \mathrm{NaOH}$. The proton and free cadmium concentrations were determined simultaneously by means of an Ingold glass electrode and an Orion Cd-ISE model 9448, respectively, using a double junction Orion 90-02 Ag/AgCl reference electrode, attached to Crison GLP $22 \mathrm{pH}$ meters. Both ion selective electrodes were previously calibrated as a function of the respective free ion concentrations $\left(\left[\mathrm{H}^{+}\right]\right.$ and $\left.\left[\mathrm{Cd}^{2+}\right]\right)$ in blank solutions of the background electrolyte $\left(0.05 \mathrm{M} \mathrm{NaNO}_{3}\right)$.

\section{Results and discussion}

\subsection{Kinetics of adsorption}

Figure 1 shows the kinetics of cadmium adsorption onto the different algae. The plots represent the amount of metal adsorbed, $\mathrm{q}_{\mathrm{t}}$, versus time for an initial cadmium concentration of $2.22 \mathrm{mmol} \cdot \mathrm{L}^{-1}$. The cadmium uptake is relatively fast for all the algae studied. In general, the system reaches over $50 \%$ of the total biomass cadmium uptake within 5 minutes of contact and it is observed that over $90 \%$ of total adsorption is removed from solution in the first 25 minutes of stirring for all the algae. 
According to these results, it was set a contact time of 3 hours for the subsequent experiments, in order to ensure that equilibrium conditions are attained. This equilibrium time is shorter than those usually employed for the adsorption of cadmium by other adsorbent materials. Times of 24 hours are proposed for the adsorption by chitin (Benguella and Benaissa, 2002), chitosan beads (Becker et al., 2000), Bakers's yeast (Vasudevan et al., 2003) or Pinus pinaster bark (Vázquez et al., 2002). Even longer times are necessary with some carbonaceous materials (72 hours) (Hanzlík et al., 2004) or activated carbon (3-5 days) (Leyva-Ramos et al., 1997). Similar equilibrium times are obtained for other algae. For instance, Aksu reported 4 hours with the microalgae Chlorella vulgaris (Aksu, 2001) whereas equilibration times of 2 or 3 hours were employed with macroalgae of the Sargassum genus (Cruz et al., 2004; Lodeiro et al., 2004).

The fast cadmium uptake observed for the different algae represents a clear advantage for practical uses, as it will facilitate shorter adsorption columns ensuring, in principle, efficiency and economy.

In order to investigate the mechanism of biosorption and potential rate controlling step such as mass transport and chemical reaction processes, kinetic models have been used to test experimental data. When the biomass is employed as a free suspension in a well-agitated batch system, the effect of external film diffusion on biosorption rate can be assumed not significant and ignored in any kinetic analysis.

The kinetic models tested included pseudo-first order, pseudo-second order and Elovich equation. Elovich and first order models only achieved a good fitting for the first minutes of experimental data. The best fits, in the whole data range, were found with a pseudo-second order equation, indicating that the rate-limiting step is a chemical sorption process between cadmium and alga. Similar conclusions were found by Ho and 
McKay as a result of a detailed analysis of data from the literature. They reported that most of the sorption systems follow a pseudo-second order kinetic model (Ho and McKay, 1999). However, the fact that experimental data may be fitted by a given rate expression is not sufficient evidence that the molecularity of the reaction is that implied by the rate law. The kinetic rate equation of the pseudo-second order chemical sorption process was proposed by Ho (Ho, 2003; Ho et al., 1996), and is given by:

$$
\frac{\mathrm{dq}_{\mathrm{Cd}, \mathrm{t}}}{\mathrm{dt}}=\mathrm{k} \cdot\left(\mathrm{Q}_{\mathrm{Cd}}-\mathrm{q}_{\mathrm{Cd}, \mathrm{t}}\right)^{2}
$$

where $k\left(\mathrm{~g} \cdot \mathrm{mmol}^{-1} \cdot \mathrm{min}^{-1}\right)$ is the pseudo-second order constant of sorption, $\mathrm{Q}_{\mathrm{Cd}}$ $\left(\mathrm{mmol} \cdot \mathrm{g}^{-1}\right)$ is the cadmium ion sorbed at equilibrium (i.e., the metal uptake) given by Eq. (2), and $\mathrm{q}_{\mathrm{Cd}, \mathrm{t}}$ is the amount of cadmium ion adsorbed at any time, $\mathrm{t}(\mathrm{min})$.

Separating variables in Equation (4) and integrating for the boundary conditions $q_{C d, t}=0$ at $t=0$ and $q_{C d, t}$ at time $t$, the following equation is obtained:

$$
\mathrm{q}_{\mathrm{Cd}, \mathrm{t}}=\frac{\mathrm{Q}_{\mathrm{Cd}}^{2} \mathrm{k} \cdot \mathrm{t}}{1+\mathrm{Q}_{\mathrm{Cd}} \mathrm{k} \cdot \mathrm{t}}
$$

which can be linearized to the following equation:

$$
\frac{\mathrm{t}}{\mathrm{q}_{\mathrm{Cd}, \mathrm{t}}}=\frac{1}{\mathrm{k} \cdot \mathrm{Q}_{\mathrm{Cd}}^{2}}+\frac{1}{\mathrm{Q}_{\mathrm{Cd}}} \cdot \mathrm{t}
$$

The equilibrium sorption capacity, $Q_{C d}$, and the pseudo-second order rate constant, $k$, were experimentally determined from slope and intercept of straight-line plots of $t / q_{C d, t}$ against $t$ and are shown in Table 1 . All the fits show very good regression coefficients and good compliance between predicted curves and the experimental data points were found (Figure 1).

\subsection{Equilibrium studies}


The cadmium uptake capacity of the biomaterial was tested by means of simple batch sorption experiments performed with the raw material in deionized water (without electrolyte addition). The results (see Figure 2) could be described satisfactorily through an empirical Langmuir isotherm, which represents a simple and widespread equation for the quantitative comparison of the sorption performance of different materials:

$$
\mathrm{Q}_{\mathrm{Cd}}=\frac{\mathrm{Q}_{\mathrm{max}, \mathrm{Cd}} \mathrm{bc}_{\mathrm{Cd}}}{1+\mathrm{bc}_{\mathrm{Cd}}}
$$

This equation includes two easily interpretable constants ( $\mathrm{Q}_{\max , \mathrm{Cd}}$ and b) that reflect the features of the sorbent, representing the maximum biosorption capacity and the affinity for the sorbate, respectively. A high value of parameter b indicates a steep initial sorption isotherm slope. A curve with a high parameter b indicates a sorbent which has a high capacity for the sorbate in the low residual concentration range. However, these empirical parameters are conditional values, in the sense that are valid only for the experimental conditions ( $\mathrm{pH}$, ionic strength, etc.) under which they have been obtained. Table 2 lists the parameter values obtained from the best fits of Eq. (7) to the experimental points shown in Figure 2. The maximum uptakes $\left(\mathrm{Q}_{\max , \mathrm{Cd}}\right)$ are in the range between $0.6-0.8 \mathrm{mmol} \cdot \mathrm{g}^{-1}$, which correspond to an average value of around $80 \mathrm{mg}$ of Cd per gram of raw seaweed, equivalent to $8 \%$ of the total dry weight of the sorbent. This value is in agreement with the cadmium sorption capacities reported for other marine macroalgae (Cruz et al., 2004; Davis et al., 2003; Lodeiro et al., 2004). It must be pointed out that, compared to other adsorbent materials proposed in literature for metal recovery applications, the seaweeds used in the present study show remarkably higher cadmium biosorption ability. For instance, values of 0.07 and $0.13 \mathrm{mmol} \cdot \mathrm{g}^{-1}$ have been reported for activated carbon (Leyva-Ramos et al., 1997) and chitin (Benguella and Benaissa, 2002), respectively. 
The fact that metal biosorption by brown algae is strongly dependent on the solution pH is well documented in bibliography (Schiewer and Volesky, 2000; Wase and Forster, 1997). This behaviour is also observed in the results of the present study. A representative example, corresponding to $F$. serratus at two different initial metal concentrations, is shown in Figure 3 (the other two seaweed species led to similar curves). It is seen that the plot of metal bound vs. $\mathrm{pH}$ displays an $\mathrm{S}$ shape centred at $\mathrm{pH}$ 3-4. This curve is characteristic of other seaweeds (Lodeiro et al., 2004) and it has been interpreted as a result of the change in the ionic state of the acid functional groups involved in the metal binding. In fact, the carboxylic groups from alginic acid (which are the most abundant binding sites in seaweeds) present a dissociation constant (in log units) between 3 and 4 (Rey-Castro et al., 2004a). At pH values below 2 the cadmium uptake is very small, but not negligible, which can be a result of the presence of a relatively low amount of very strong acid groups like sulfonic groups from fucoidans (Fourest and Volesky, 1996). Above pH 5 the increase in the metal sorption is almost negligible, and the uptake reaches a plateau.

The acid-base titrations of protonated biomass samples allow the estimation of the maximum amount of acid functional groups, $\mathrm{Q}_{\max , \mathrm{H}}$ (see Table 3 ). This amount is 3 or 4 times greater than the maximum cadmium uptake capacities obtained with raw biomass. This fact can be explained as a combination of factors. First, since the raw biomass is stabilized with $\mathrm{Na}, \mathrm{K}$, Ca and $\mathrm{Mg}$ ions present in seawater, cadmium ions must compete with these major ions for the active binding sites, and therefore not all the binding sites are occupied by the heavy metal. Second, it can be expected a certain degree of multidentism in the binding mechanism, i.e., more than one acid group can be involved in the binding to a single metal ion. 
3.3. Interpretation of proton and metal binding in terms of competitive adsorption isotherms

One of the main goals of biosorption studies is to develop a model for the binding behaviour of the biomaterials towards the metal ions. This model would eventually constitute a useful tool for the prediction of the toxic metal partition between the aqueous phase and the sorbent in flow-through column systems for wastewater treatment. Ideally, such a model should be able to account for the influence of environmental variables such as $\mathrm{pH}$, ionic strength, presence of competing cations, etc.

The development of such a model is hindered by several effects commonly present in complexation phenomena of macromolecular systems (Buffle, 1988). First, the major binding sites in brown algae are usually attributed to the carboxylic groups of the alginates and other acid polysaccharides (Davis et al., 2003; Schiewer and Wong, 2000). However, other less abundant functional groups such as sulphonic groups from fucoidans and, to a lesser extent, $\mathrm{N}$ - and S- containing groups from proteins may also be important for metal ion binding. As a consequence of this chemical heterogeneity, there will be a more or less broad range of affinities for the inorganic ions. Second, most of these functional groups are ionized at the experimental $\mathrm{pH}$ values. This relatively high local charge density creates an electric field that influences the stability of the metal complexes, regardless the chemical nature of the binding site involved. This polyelectrolytic effect contributes to the apparent (overall) affinity for the charged species (protons or metal cations) and is responsible for what is called non-specific binding. Third, the steric conformation of the sorbent polymers can vary with the chemical conditions in the medium, such as ionic strength, $\mathrm{pH}$ and amount of metal ions. Among these conformational effects, it can be mentioned, for instance, the swelling/shrinking behaviour of the biomass particles, the leaching of soluble organic 
matter from the biomass and, what is of most interest in brown algae, the formation of the characteristic alginate arrangement known as the egg-box structure (Davis et al., 2003; Percival and McDowell, 1967). This structure is induced by the presence of divalent ions (like $\mathrm{Ca}^{2+}$ ), which favour the interchain cross-linking of the alginate (in particular, the poly-guluronic sections). In this way, the alginate chains yield an array of cavities (formed by the guluronic residues) stabilized by the divalent ions.

The starting point in the development of a physical-chemical model for the description of metal ion binding to seaweed biomass is the description of proton binding as a function of $\mathrm{pH}$ in 1:1 electrolytes. Schiewer and Volesky (Schiewer and Volesky, 1997b) proposed the use of a Donnan electrostatic model (with empirical functions for the correction of the particle swelling) in combination with a single discrete site model for the intrinsic proton binding to seaweeds of the genus Sargassum.

Rey Castro et al. (Rey-Castro et al., 2003) reported proton binding data from potentiometric titrations of biomass from different seaweed species (Sargassum, Cystoseira and Saccorhiza sp.) in $\mathrm{NaCl}$ and $\mathrm{KNO}_{3}$. These authors chose an alternative approach consisting in a continuous distribution of affinities represented by the Langmuir-Freundlich (LF) isotherm. The advantage in the use of this isotherm is that it only involves one additional parameter compared with a homogeneous model (Langmuir isotherm). This extra parameter characterizes the width of the distribution (the chemical heterogeneity). It was shown that a unimodal LF isotherm was enough to describe successfully the experimental data in the range $2.5<\mathrm{pH}<7$. On a subsequent paper, Rey Castro et al. (Rey-Castro et al., 2004b) analysed the use of different electrostatic descriptions of the polyelectrolytic effect, showing a comparison between Donnan model and a simplified Gouy-Chapman model for the diffuse layer. 
The models for proton and metal binding to natural organic matter that have been developed so far are quite involved and contain a large number of model parameters, which is a consequence of the underlying complexity of the systems.

The extension of the model from a single component (proton) to the general multi-component case (competitive ion binding) is a major challenge. The first common assumption in most physicochemical models is that, in principle, all specifically bound cations including proton should be able to compete for the same sites. In this aspect, the native biomass represents an additional problem, since protons and cadmium ions must compete not only with each other, but also with the light metal ions $\left(\mathrm{Na}^{+}, \mathrm{K}^{+}, \mathrm{Ca}^{2+}\right.$, $\mathrm{Mg}^{2+}$, etc.) already present in the cell wall as counterions of the alginate groups. Crist et al. (Crist et al., 1994; Crist et al., 1990; Crist et al., 1992) demonstrated through careful mass balances that these ions are exchangeable with protons. In order to avoid this effect and simplify the system, only the binding data obtained with acid-treated biomass (which is supposed to be completely free of exchangeable metals) are used in this work for modelling purposes.

The literature about humic substances has paid much attention to the study of competitive ion binding. Very recently, a non-ideal competitive adsorption model (NICCA) was developed (Kinniburgh et al., 1999) (and references therein) for humic and fulvic acids. This model is a semi-empirical, thermodynamically consistent model, which implicitly accounts for a variable degree of heterogeneity of the sorbent. The basic NICCA equation for the overall binding of species $i$ in the competitive situation is:

$$
\theta_{i}=\frac{\left(\widetilde{\mathrm{K}}_{\mathrm{i}} \mathrm{c}_{\mathrm{i}}\right)^{\mathrm{n}_{\mathrm{i}}}}{\sum_{\mathrm{i}}\left(\widetilde{\mathrm{K}}_{\mathrm{i}} \mathrm{c}_{\mathrm{i}}\right)^{\mathrm{n}_{\mathrm{i}}}} \frac{\left[\sum_{\mathrm{i}}\left(\widetilde{\mathrm{K}}_{\mathrm{i}} \mathrm{c}_{\mathrm{i}}\right)^{\mathrm{n}_{\mathrm{i}}}\right]^{\mathrm{p}}}{1+\left[\sum_{\mathrm{i}}\left(\widetilde{\mathrm{K}}_{\mathrm{i}} \mathrm{c}_{\mathrm{i}}\right)^{\mathrm{n}_{\mathrm{i}}}\right]^{\mathrm{p}}}
$$


where $\theta_{i}$ is the coverage fraction of the species $i, \widetilde{K}_{i}$ is the median value of the affinity distribution for species $\mathrm{i}, \mathrm{p}$ is the width of the distribution (usually interpreted as a generic or intrinsic heterogeneity seen by all ions) and $n_{i}$ is an ion-specific non-ideality term. Strictly speaking, $\mathrm{c}_{\mathrm{i}}$ should be the local concentration of species $\mathrm{i}$ at the binding site, i.e., the bulk concentration (or activity) corrected for the double layer effect (for instance, the concentrations in the Donnan phase). In this work, the bulk concentrations will be used instead and, therefore, the metal binding constants calculated will be conditional parameters (referred to $0.05 \mathrm{M}$ ionic strength).

The following normalization condition is used to calculate the amount of species i bound, $\mathrm{Q}_{\mathrm{i}}$ :

$$
\mathrm{Q}_{\mathrm{i}}=\theta_{\mathrm{i}}\left(\mathrm{n}_{\mathrm{i}} / \mathrm{n}_{\mathrm{H}}\right) \mathrm{Q}_{\mathrm{max}, \mathrm{H}}
$$

where $\mathrm{Q}_{\mathrm{max}, \mathrm{H}}$ is the maximum binding capacity for protons (Table 3), which has been calculated from the equivalence point of the acid-base titrations in absence of heavy metal.

The ratio $\mathrm{n}_{\mathrm{i}} / \mathrm{n}_{\mathrm{H}}$ has been interpreted by Kinniburgh et al (Kinniburgh et al., 1999) in terms of stoichiometry and cooperativity. When this ratio is less than one, then the maximum binding of species $\mathrm{i}$ is lower than the total amount of sites (defined as the amount of titratable protons), which would be a consequence of some degree of multidentism. On the other hand, a value of $\mathrm{n}_{\mathrm{i}} / \mathrm{n}_{\mathrm{H}}$ greater than one would reflect some degree of cooperativity. Finally, if $\mathrm{n}_{\mathrm{i}} / \mathrm{n}_{\mathrm{H}}=1$, it can be demonstrated that the maximum proton/metal exchange ratio is one.

We see that if $n_{i}=n_{H}=1$, then the NICCA isotherm reduces to the generalized (multicomponent) Langmuir-Freundlich isotherm (GLF): 


$$
\theta_{\mathrm{i}}=\frac{\left(\widetilde{\mathrm{K}}_{\mathrm{i}} \mathrm{c}_{\mathrm{i}}\right)}{\sum_{\mathrm{i}}\left(\widetilde{\mathrm{K}}_{\mathrm{i}} \mathrm{c}_{\mathrm{i}}\right)} \frac{\left[\sum_{\mathrm{i}}\left(\tilde{\mathrm{K}}_{\mathrm{i}} \mathrm{c}_{\mathrm{i}}\right)\right]^{\mathrm{p}}}{1+\left[\sum_{\mathrm{i}}\left(\tilde{\mathrm{K}}_{\mathrm{i}} \mathrm{c}_{\mathrm{i}}\right)\right]^{\mathrm{p}}}
$$

Note also that if only the proton binding is considered (i.e., absence of competing ions) in Eqs. (8) and (9), then the LF isotherm is recovered:

$$
\mathrm{Q}_{\mathrm{H}}=\mathrm{Q}_{\text {max,H }} \frac{\left(\widetilde{\mathrm{K}}_{\mathrm{H}} \mathrm{C}_{\mathrm{H}}\right)^{\mathrm{m}_{\mathrm{H}}}}{1+\left(\widetilde{\mathrm{K}}_{\mathrm{H}} \mathrm{c}_{\mathrm{H}}\right)^{\mathrm{m}_{\mathrm{H}}}}
$$

where now the heterogeneity parameter $m_{H}$ describes the combined effect of $n_{H}$ and $p$ $\left(m_{H}=n_{H} \cdot p\right)$. In the case of a homogeneous system (no chemical heterogeneity), $m_{H}=1$ and then the Langmuir isotherm is obtained. For instance, the ideal Langmuir competitive isotherm for the binding of $\mathrm{Cd}^{2+}$ (assuming a 1:1 stoichiometry) would be:

$$
\theta_{\mathrm{Cd}}=\frac{\mathrm{K}_{\mathrm{Cd}} \mathrm{C}_{\mathrm{Cd}}}{1+\mathrm{K}_{\mathrm{H}} \mathrm{C}_{\mathrm{H}}+\mathrm{K}_{\mathrm{Cd}} \mathrm{C}_{\mathrm{Cd}}}
$$

with $\mathrm{Q}_{\mathrm{Cd}}=\theta_{\mathrm{Cd}} \cdot \mathrm{Q}_{\max , \mathrm{H}}$.

The procedure followed in this section is as follows. The proton binding data obtained in $0.05 \mathrm{M} \mathrm{NaNO}_{3}$ (in absence of cadmium) was used to obtain the best fit values of the conditional parameters in Eq. (11) $\left(\mathrm{Q}_{\max , \mathrm{H}}, \log \tilde{\mathrm{K}}_{\mathrm{H}}\right.$ and $\left.\mathrm{m}_{\mathrm{H}}\right)$. These values are assumed to apply also in the presence of $\mathrm{Cd}^{2+}$. The values of the binding parameters for the cadmium ion $\left(\log \widetilde{K}_{\mathrm{Cd}}, \mathrm{n}_{\mathrm{Cd}}\right.$, $\left.\mathrm{p}\right)$ are then obtained from the simultaneous fit of Eqs. (8)-(9) to the metal ion adsorption isotherms at different $\mathrm{pH}$ values.

On the basis of the great similarity among the three algae investigated, only one of them, F. serratus, was chosen to exemplify the application of the competitive adsorption model.

The proton binding data obtained in absence of cadmium is shown in Figure 4. It has already been mentioned that, under these conditions, the NICCA equation is 
reduced to a LF isotherm, Eq. (11). As can be observed in Figure 4, the fit of this equation to the experimental data is very good. Similar results have been obtained with the other Fucus species (see Table 3). Moreover, the values of the binding constants, the heterogeneity parameters and the specific amount of acid groups are very similar to the values obtained with other seaweed species (Rey-Castro et al., 2003).

The results of the above analysis of the proton binding data will be taken as fixed in all subsequent calculations using the NICCA model. The separation of $n_{H}$ and $p$ was made using the constraint $m_{H}=n_{H} \cdot p$.

The results of the batch metal sorption experiments performed with acid-treated biomass samples of $F$. serratus at different $\mathrm{pH}$ values are shown in Figure 5. The $\mathrm{pH}$ dependence in $\mathrm{Cd}(\mathrm{II})$ binding appears quite high at low $\mathrm{pH}$ values, with the amount of cadmium bound varying by more than one order of magnitude between $\mathrm{pH} 3$ and 4.5; and very small above $\mathrm{pH} 4.5$, which is in agreement with the data shown in Figure 3. Again, this behaviour is explained by the fact that the main acid functionalities in the biomass are the carboxylic groups from alginate, which dissociate between $\mathrm{pH} 3$ and 4 .

The data at pH 6 and low $\mathrm{Cd}^{2+}$ concentration do not appear to fit the model well. In fact, the isotherm presents an unusual "S" profile, rather than the common Langmuirian shape. The influence of hydrolysis can be discarded, since the cadmium ions start to undergo hydrolysis at much higher values (above $\mathrm{pH}$ 8). Instead, the anomalous shape of the isotherm at this relatively high $\mathrm{pH}$ can be explained as a result of the partial solubilization of the biomass, which is known to release alginates (specially in absence of divalent cations that stabilize the polysaccharide lattice by cross-linking) at relatively high $\mathrm{pH}$ values. The alginate in aqueous phase can still bind cadmium ions, which therefore, would pass the $0.45 \mu \mathrm{m}$ filter. It is known that the Cd(II) complexes with alginic acid and other acid polysaccharides are labile in the 
conditions used in the voltammetric technique (Nadal et al., 1991). Hence, the DPASV measurements of the filtrate solutions will give the total amount of dissolved Cd(II), as was checked by comparison with atomic absorption spectroscopy measurements. However, the amount of free aqueous $\mathrm{Cd}^{2+}$ is expected to be somewhat lower, which was demonstrated by Cd ion-selective electrode potentiometry. For instance, Figure 6 shows the results of DPASV and Cd-ISE measurements of the same filtrate solutions at $\mathrm{pH}$ 6. It can be observed that the difference between dissolved $\mathrm{Cd}$ and free $\mathrm{Cd}^{2+}$ decreases as the total amount of metal increases, due to the fact that high amounts of the divalent cation tend to stabilize the alginate layer by gelation and cross-linking. This difference is much smaller at $\mathrm{pH}$ values below 5 , since in these conditions the solubility of alginic acid is very small. It must be pointed out that the interesting magnitude for technological applications is the total amount of dissolved heavy metal in the filtrates. Odd "S-shaped" isotherms, attributed to partial solubilization of organic matter, have also been described in the study of metal sorption in soils (Drexel et al., 2002) (and references therein).

The fit of the NICCA model to the cadmium binding data (discarding the data at pH 6 and lower metal concentrations) is satisfactory (see Figure 5). On the other hand, the fit of the NICCA model to the Cd-ISE binding data at $\mathrm{pH} 6$ for the whole set of data is shown in Figure 6. It can be observed that the fit is slightly better but not entirely acceptable.

As a matter of comparison, the best fit to a simple Langmuir competitive isotherm is also shown in Figure 5. In the latter case, Eq. (12) was used with $\mathrm{K}_{\mathrm{H}}$ fixed to the value obtained from the Langmuir fit of the proton binding data (dotted line in Figure 4). It can be observed that although the slope of the competitive Langmuir equation agrees with the experimental slope of the isotherms in the $\log \mathrm{Q}_{\mathrm{Cd}} \mathrm{vs}$. $-\log \mathrm{c}_{\mathrm{Cd}}$ 
plot, this equation is not able to reproduce the $\mathrm{pH}$ effect. This is due to the fact that Langmuir isotherm assumes a homogeneous ligand behaviour (i.e., an affinity distribution represented by a discrete value of the binding constant). A competitive Langmuir isotherm equation for 1:2 complexes between $\mathrm{Cd}$ and algal ligand gives neither the correct slope nor an adequate spacing of the isotherms as a function of $\mathrm{pH}$ (graph not shown). On the contrary, the NICCA equation is successful in describing the experimental slope of the isotherms as well as the $\mathrm{pH}$ dependency.

The best-fit parameter values of the NICCA model for acid-treated biomass of $F$. serratus, which correspond to the solid lines plotted in Figure 5, are listed in Table 3. Since the value of the ratio $\mathrm{n}_{\mathrm{Cd}} / \mathrm{n}_{\mathrm{H}}$ is slightly lower than one (in fact, 0.8 ), the maximum metal binding is somewhat lower than the total number of acid sites, which would reflect a certain degree of multidentism. However, it must be pointed out that the NICCA isotherm does not require a priori assumptions about the binding stoichiometry (Kinniburgh et al., 1999).

The values listed in Table 3 were used to predict the proton and metal binding in a continuous acid-base titration of $F$. serratus in presence of a $2.22 \mathrm{mmol} \cdot \mathrm{L}^{-1}$ initial cadmium concentration, using $\mathrm{H}^{+}$and $\mathrm{Cd}^{2+}$ ion selective electrodes. The comparison between experimental results and model predictions is shown in Figure 7. Note the good agreement of the NICCA isotherm with the experimental data, using the model parameters previously estimated from the batch sorption experiments and acid-base titrations in absence of metal.

It must be pointed out that from data obtained at a single ionic strength it is not possible to estimate the relative contribution of specific and electrostatic bindings. In fact, it is expected that the total amount of the cadmium retained by the biomass would comprise two different fractions, one consisting of metal ions specifically bound to the 
functional sites, and another one consisting of $\mathrm{Cd}^{2+}$ ions retained by electrostatic attraction to the negative charge developed in the polymeric matrix of the cell walls.

\section{Conclusions}

The preliminary results of this work indicate that the brown marine algae Fucus sp. may constitute a promising material for the development of a low cost biosorption technology for the removal of cadmium from water effluents. The fast kinetics of the sorption process together with the high sorption capacities of these seaweeds towards cadmium can be compared favourably with other sorbents.

Furthermore, this work emphasizes the need to develop a physicochemical model for the prediction of the metal partition between the sorbent and the aqueous phase under some given conditions of $\mathrm{pH}$ or metal concentration. With this purpose, a thermodynamically consistent empirical isotherm was applied to the study of the competition between protons and cadmium ions. A more rigorous application of the model with the aim of deriving the intrinsic binding parameters (i.e., independent of the bulk ionic strength) would require the knowledge of the geometric parameters that determine the electrostatic description of the system. In the case of the Donnan model (NICCA-Donnan) applied to humic substances, it is often assumed that this parameter (the Donnan volume) is not affected by the metal ion adsorption. Unfortunately, at the high metal ion coverages of the biosorption studies, there is some experimental evidence (Schiewer and Volesky, 1997a) that this assumption does not hold for seaweed biomass. Consequently, further experimental work regarding metal sorption studies at different ionic strengths would be required in the future.

Moreover, the release of organic matter from the sorbent particles is believed to represent an important role for the performance of the sorption process at relatively high 
$\mathrm{pH}$ values. This effect will require further investigation, for instance, the study of the influence of the environment conditions ( $\mathrm{pH}$, ionic strength, amount of divalent cations) and the use of chemical pretreatments (like cross-linking reactions) to prevent the loss of organic matter.

\section{Acknowledgements}

This work was funded by the projects BQU2002-02133 (from the Ministerio de Ciencia y Tecnología of Spain) and PGDIT02TAM10302PR (from the Xunta de Galicia). The authors would like to thank Dr. I. Bárbara and Dr. J. Cremades (U. of A Coruña) for the collection and classification of the species. 


\section{TABLES}

\section{Table 1}

Parameters obtained from the pseudo-second order rate reaction. $2.5 \mathrm{~g} \mathrm{~L}^{-1}$ of algal dose (raw biomass) with ionic strength adjusted to $0.05 \mathrm{M}$ with $\mathrm{NaNO}_{3}$ at 2.22 $\mathrm{mmol} \cdot \mathrm{L}^{-1}$ initial cadmium concentration.

\begin{tabular}{cccc}
\hline Species & $\begin{array}{c}\text { QCd } \\
\mathbf{( m m o l \cdot g} \mathbf{- 1})\end{array}$ & $\begin{array}{c}\mathbf{k} \\
(\mathbf{g ~ m m o l}\end{array}$ & $\left.\mathbf{r}^{\mathbf{2}} \mathbf{~ m i n}^{-\mathbf{1}}\right)$ \\
\hline F. ceranoides & $0.609(0.001)$ & $0.64(0.04)$ & 0.9998 \\
F. serratus & $0.522(0.002)$ & $0.58(0.04)$ & 0.9997 \\
F. vesiculosus & $0.578(0.003)$ & $0.38(0.03)$ & 0.9991 \\
\hline
\end{tabular}

Table 2

Optimal Langmuir isotherm parameter estimates for cadmium binding by the raw biomass at $\mathrm{pH} 4.5$

\begin{tabular}{cccc}
\hline Species & $\begin{array}{c}\text { Qmax,Cd } \\
\left(\mathbf{m m o l} \cdot \mathbf{g}^{-1}\right)\end{array}$ & Log b & $\mathbf{r}^{2}$ \\
\hline F. ceranoides & $0.65(0.02)$ & $0.76(0.05)$ & 0.994 \\
F. serratus & $0.72(0.04)$ & $0.51(0.07)$ & 0.990 \\
F. vesiculosus & $0.79(0.05)$ & $0.61(0.09)$ & 0.980 \\
\hline
\end{tabular}




\section{Table 3}

Optimal parameter estimates for proton and cadmium binding by the acid-treated biomass in $0.05 \mathrm{M} \mathrm{NaNO}_{3} .{ }^{\text {a }}$ Estimated from the equivalence point of the acid-base titrations performed in absence of heavy metal. ${ }^{\mathrm{b}}$ Calculated from least-squares fit of the LF isotherm, Eq. (11), to the proton binding data. ${ }^{\mathrm{c}}$ Calculated from least-squares fit of the NICCA isotherm, Eqs. (8)-(9), to the cadmium sorption data.

\begin{tabular}{|c|c|c|c|}
\hline \multirow[b]{2}{*}{ Species } & \multicolumn{3}{|c|}{ Proton binding parameters } \\
\hline & 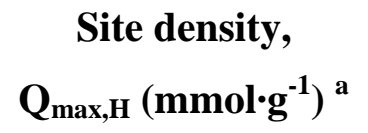 & $\log \tilde{K}_{H}^{b}$ & $\mathbf{m}_{\mathbf{H}}=\mathbf{p} \cdot \mathbf{n}_{\mathbf{H}} b$ \\
\hline F. ceranoides & $2.86(0.04)$ & $3.71(0.01)$ & $0.50(0.01)$ \\
\hline F. serratus & $2.89(0.01)$ & $3.70(0.01)$ & $0.60(0.01)$ \\
\hline \multirow[t]{3}{*}{ F. vesiculosus } & $2.42(0.02)$ & $3.77(0.01)$ & $0.55(0.01)$ \\
\hline & \multicolumn{3}{|c|}{ Cd(II) binding parameters } \\
\hline & $\begin{array}{l}\text { Heterogeneity } \\
\text { parameter, p }\end{array}$ & $\log \tilde{K}_{\mathrm{Cd}}{ }^{c}$ & $\mathbf{n}_{\mathbf{C d}}{ }^{\mathrm{c}}$ \\
\hline F. serratus & $0.36(0.05)$ & $2.69(0.04)$ & $1.2(0.2)$ \\
\hline
\end{tabular}




\section{FIGURE CAPTIONS}

\section{Figure 1}

Sorption of cadmium as a function of contact time, for aqueous suspensions of raw biomass of the three Fucus species in $0.05 \mathrm{M} \mathrm{NaNO}_{3}$ and $2.22 \mathrm{mmol} \cdot \mathrm{L}^{-1}$ initial cadmium concentration. The symbols correspond to the experimental points and the solid lines represent the best fits to Eq. (5).

\section{Figure 2}

Cadmium biosorption isotherms for suspensions of $2.5 \mathrm{~g} \cdot \mathrm{L}^{-1}$ of raw biomass in deionized water at $\mathrm{pH}=4.5 \pm 0.1$ and $25^{\circ} \mathrm{C}$. The symbols correspond to the experimental points and the lines represent the fits to simple Langmuir equations (solid line: $F$. ceranoides; dashed line: F. vesiculosus; dotted line: F. serratus).

\section{Figure 3}

Effect of $\mathrm{pH}$ on cadmium biosorption by $2.5 \mathrm{~g} \cdot \mathrm{L}^{-1}$ of $F$. serratus in $0.05 \mathrm{M}$ $\mathrm{NaNO}_{3}$ at $25^{\circ} \mathrm{C}$, with initial cadmium concentrations of $2.22 \mathrm{mmol} \cdot \mathrm{L}^{-1}$ (open squares) and $0.18 \mathrm{mmol} \cdot \mathrm{L}^{-1}$ (filled circles). The lines guide the eye.

\section{Figure 4}

Proton binding by F. serratus (in absence of cadmium) in $0.05 \mathrm{M} \mathrm{NaNO}_{3}$. Symbols represent experimental points (two replicate experiments are shown), solid line corresponds to the best fit of a Langmuir-Freundlich isotherm, Eq. (11), and dotted line to a simple Langmuir isotherm, equivalent to Eq. (11) with $\mathrm{m}_{\mathrm{H}}=1$. In both cases, the value of $\mathrm{Q}_{\text {max,H }}$ was set equal to the total amount of titratable groups, determined from the equivalence point of the base titrations. The best fit parameter values of the LF isotherm are listed in Table 3.

\section{Figure 5}

Cadmium binding by F. serratus at different $\mathrm{pH}$ values in $0.05 \mathrm{M} \mathrm{NaNO}_{3}$. Points are DPASV measurements (mean values), solid lines are the fitted NICCA isotherms and dotted lines represent fitted ideal competitive Langmuir isotherms (assuming 1:1 stoichiometry). 


\section{Figure 6}

Comparison between DPASV (open circles) and Cd-ISE (filled symbols) measurements of cadmium in $0.05 \mathrm{M} \mathrm{NaNO}_{3}$ solutions in equilibrum with $2.5 \mathrm{~g} \cdot \mathrm{L}^{-1}$ of acid-treated biomass of F. serratus at $\mathrm{pH}$ 6. In each case, the amount of metal bound was calculated from the difference between the initial $\mathrm{Cd}$ concentration and the measured value in the filtrates after equilibration, using Eq. (2). Solid line is the fitted NICCA isotherm of the Cd-ISE data.

\section{Figure 7}

Proton and cadmium binding measured by ISE potentiometry in a continuous titration of acid-treated biomass of $F$. serratus $\left(2.5 \mathrm{~g} \cdot \mathrm{L}^{-1}\right)$ suspended in $\mathrm{NaNO}_{3}$ with a $2.22 \mathrm{mmol} \cdot \mathrm{L}^{-1}$ initial cadmium concentration (total ionic strength of $0.05 \mathrm{M}$ ). The symbols represent experimental data (only every third point is shown for clarity) and the solid lines, predictions calculated with the NICCA equation using the parameters listed in Table 3. The dotted lines correspond to a simple Langmuir competitive isotherm. 
FIGURES

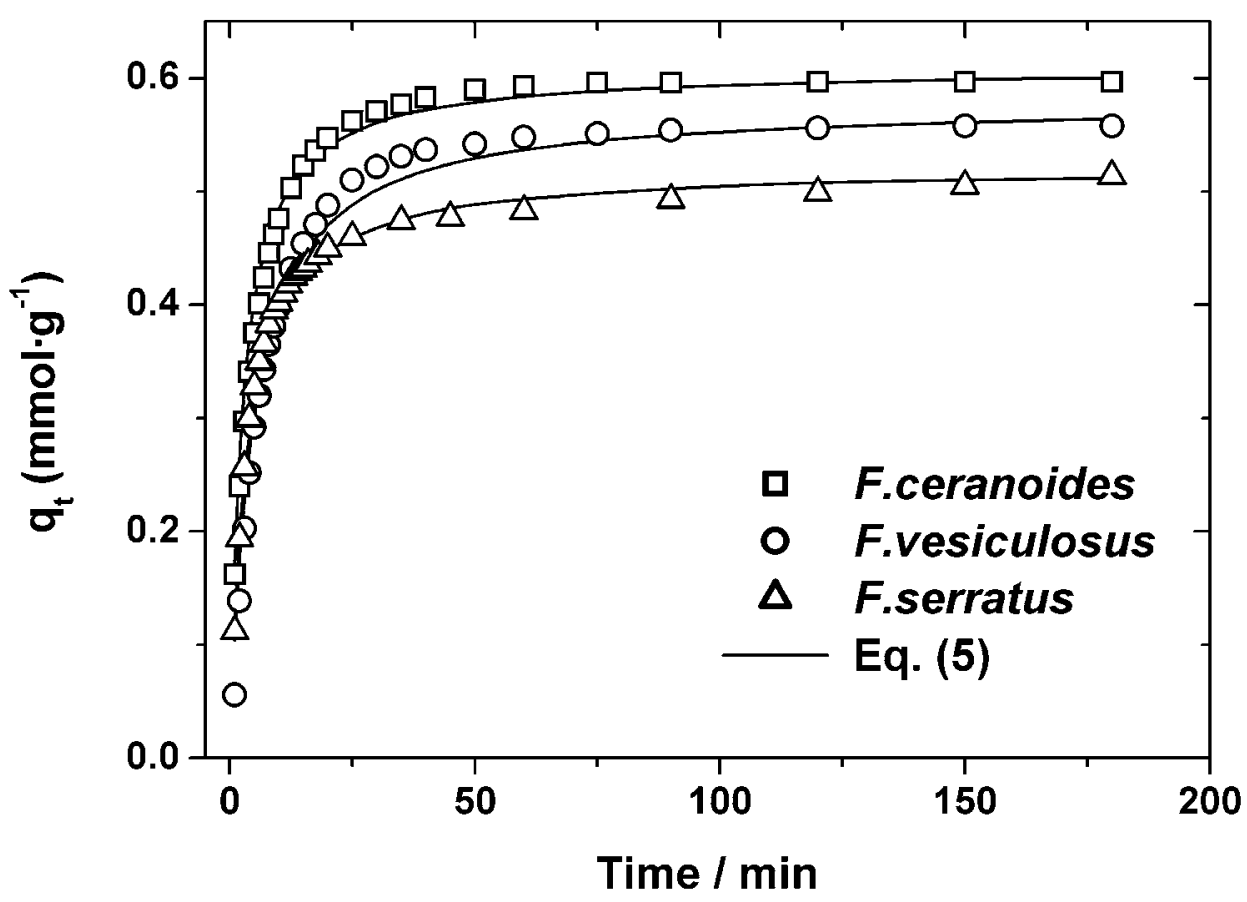

Figure 1

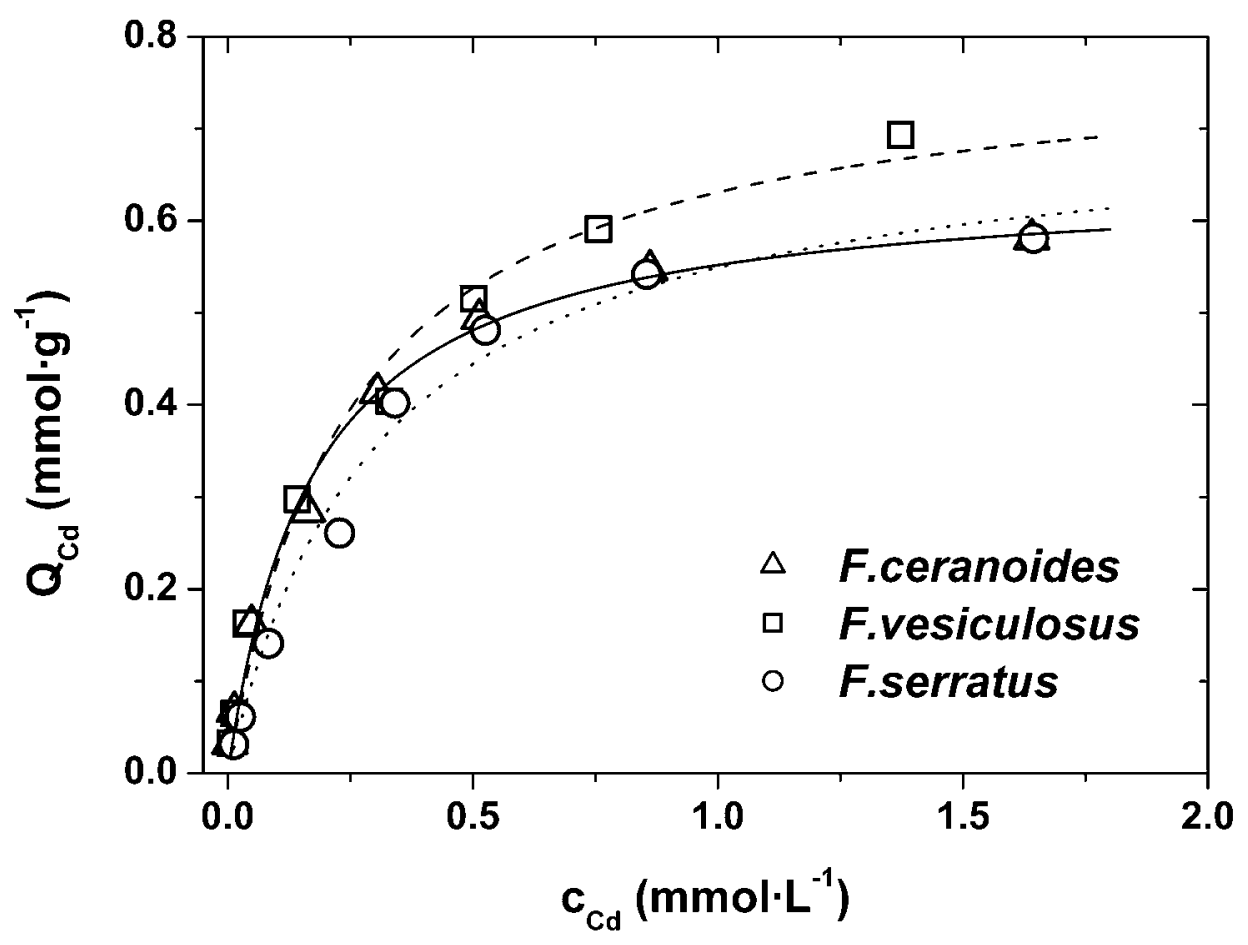

Figure 2 


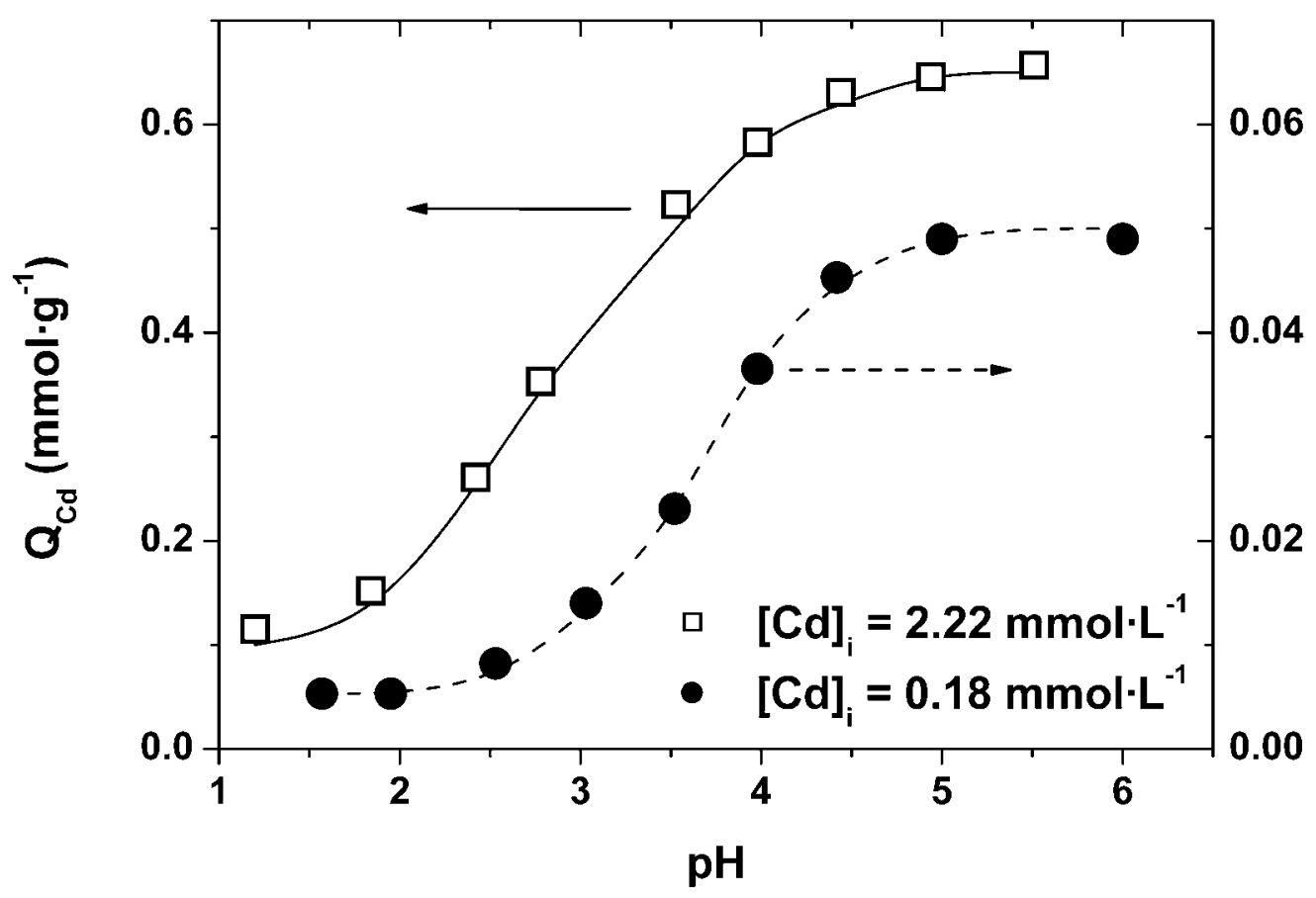

Figure 3

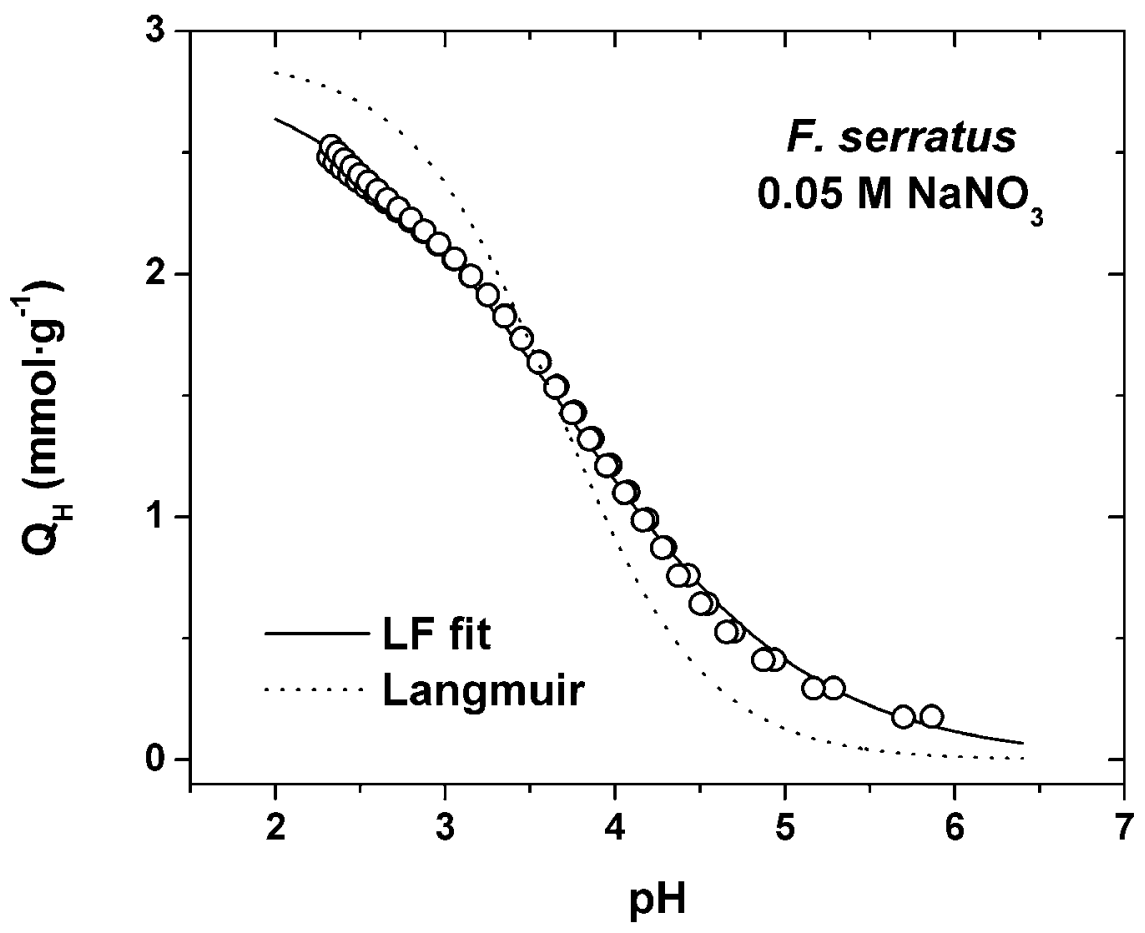

Figure 4 


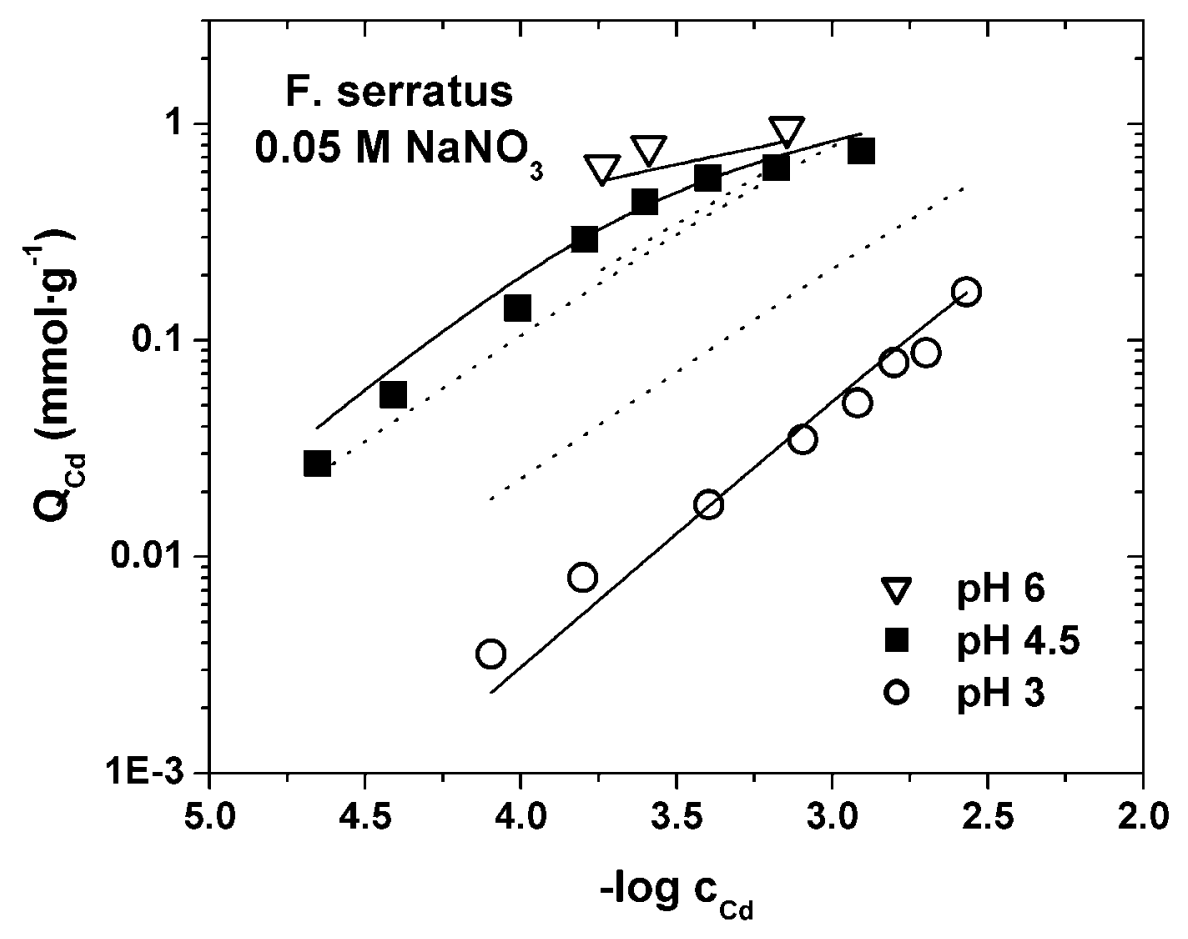

Figure 5

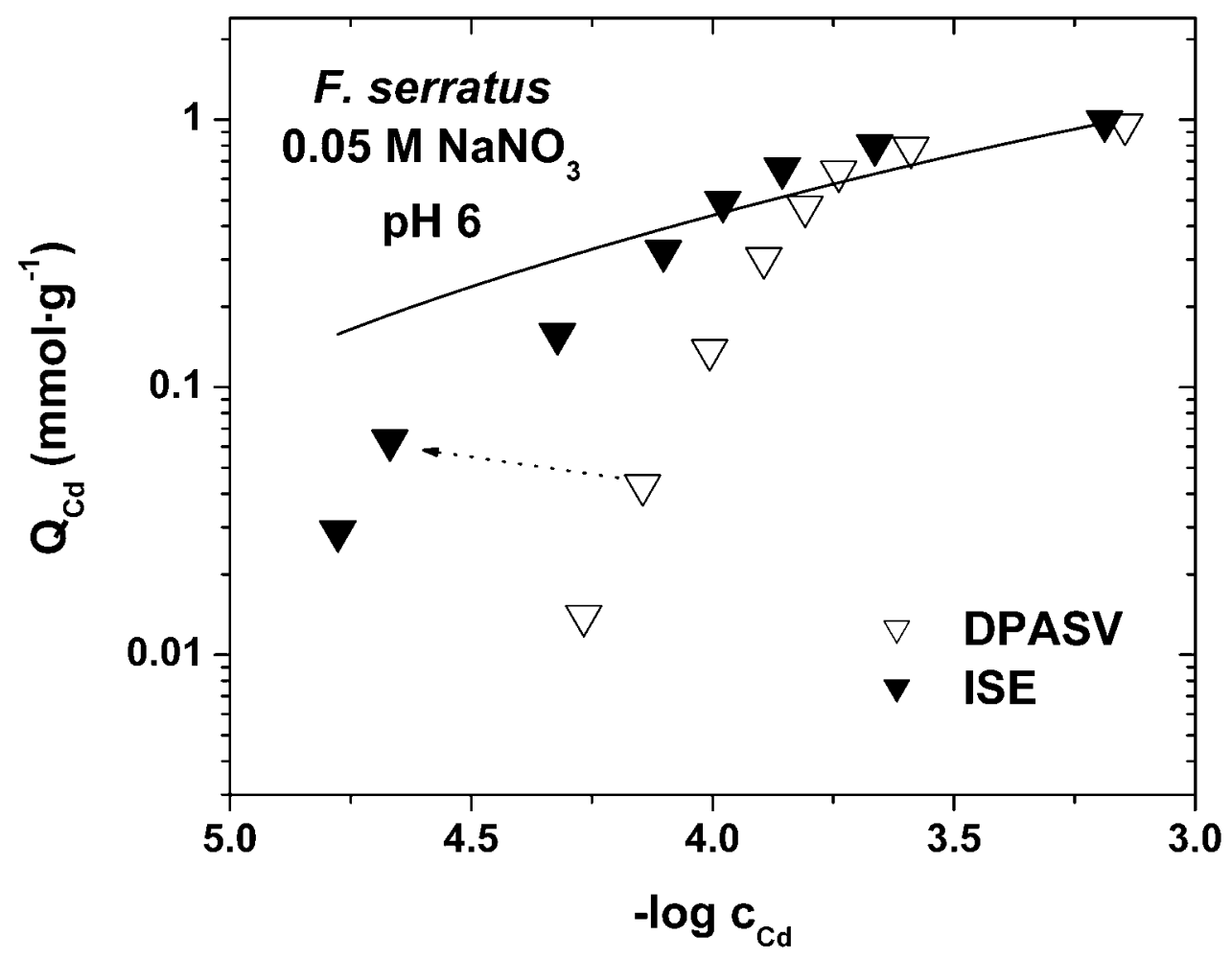

Figure 6 


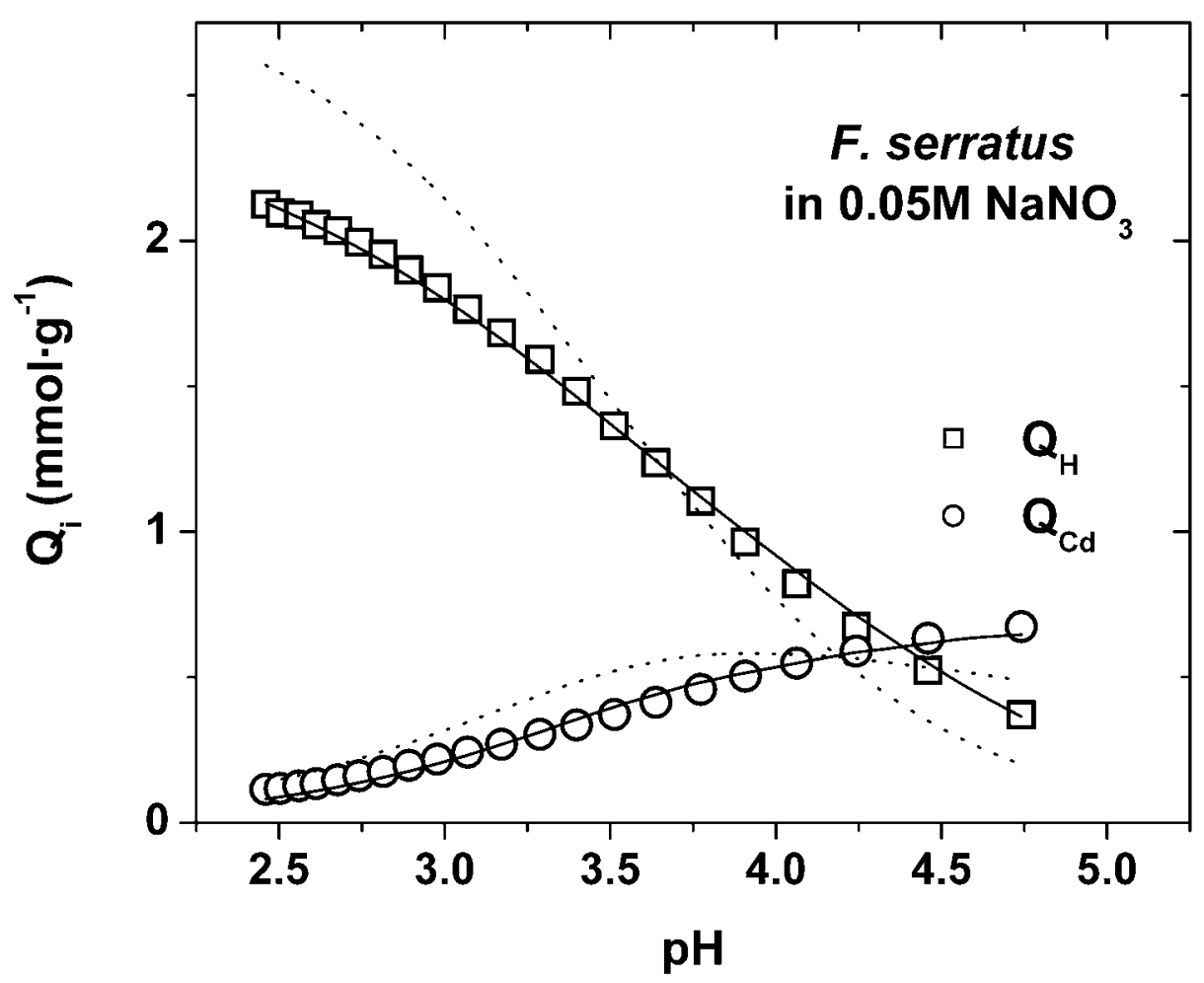

Figure 7 


\section{References}

Aksu, Z., 2001. Equilibrium and kinetic modelling of cadmium (II) biosorption by $C$. vulgaris in a batch system: effect of temperature. Separation and Purification Technology, 21: 285-294.

Becker, T., Schlaak, M. and Strasdeit, H., 2000. Adsorption of nickel (II), zinc (II) and cadmium (II) by new chitosan derivatives. Reactive \& Functional Polymers, 44: 289-298.

Benguella, B. and Benaissa, H., 2002. Cadmium removal from aqueous solutions by chitin: kinetic and equilibrium studies. Water Research, 36: 2463-2474.

Buffle, J., 1988. Complexation reactions in aquatic systems: An analytical approach. Ellis Horwood, Chichester.

Crist, D.R., Crist, R.H., Martin, J.R. and Watson, J.R., 1994. Ion exchange system in proton-metal reactions with algal cell walls. FEMS Mibrobiology Reviews, 14: 309-314.

Crist, R.H., Martin, J.R., Guptill, P.W., Eslinger, J.M. and Crist, D.R., 1990. Interaction of metals and protons with algae. 2. Ion exchange in adsorption and metal displacement by protons. Environmental Science \& Technology, 24(3): 337-342.

Crist, R.H., Oberholser, K., McGarrity, J., Crist, D.R., Johnson, J.K. and Brittsan, J.M., 1992. Interaction of metals and protons with algae. 3. Marine algae, with emphasis on lead and aluminum. Environmental Science \& Technology, 26(3): 496-502.

Cruz, C.C.V., Costa, A.C.A., Henriques, C.A. and Luna, A.S., 2004. Kinetic modeling and equilibrium studies during cadmium biosorption by dead Sargassum sp biomass. Bioresource Technology, 91: 249-257. 
Davis, T.A., Volesky, B. and Mucci, A., 2003. A review of the biochemistry of heavy metal biosorption by brown algae. Water Research, 37: 4311-4330.

Drexel, R.T., Haitzer, M., Ryan, J.N., Aiken, G.R. and Nagy, K.L., 2002. Mercury(II) sorption to two Florida Everglades peats: evidence for strong and weak binding and competition by dissolved organic matter released from the peat. Environmental Science \& Technology, 36: 4058-4064.

Fourest, E. and Volesky, B., 1996. Contribution of sulfonate groups and alginate to heavy metal biosorption by the dry biomass of Sargasum fluitans. Environmental Science \& Technology, 30(1): 277-282.

Hanzlík, J., Jehlicka, J., Sebek, O., Weishauptová, Z. and Machovic, V., 2004. Multicomponent adsorption of $\mathrm{Ag}(\mathrm{I}), \mathrm{Cd}(\mathrm{II})$ and $\mathrm{Cu}(\mathrm{II})$ by natural carbonaceous materials. Water Research, 38: 2178-2184.

Ho, Y.S., 2003. Removal of copper ions from aqueous solution by tree fern. Water Research, 37: 2323-2330.

Ho, Y.S. and McKay, G., 1999. Pseudo-second order model for sorption processes. Process Biochemistry, 34: 451-465.

Ho, Y.S., Wase, D.A.J. and Forster, C.F., 1996. Kinetic studies of competitive heavy metal adsorption by sphagnum moss peat. Environmental Technology, 17: 7177.

Kapoor, A. and Viraraghavan, T., 1995. Fungal biosorption-An alternative treatment option for heavy metal bearing wastewaters: A review. Bioresource Technology, 53: 195-206.

Kinniburgh, D.G., van Riemsdijk, W.H., Koopal, L.K., Borkovec, M., Benedetti, M.F. and Avena, M.J., 1999. Ion binding to natural organic matter: competition, 
heterogeneity, stoichiometry and thermodynamic consistency. Colloids and Surfaces A: Physicochemical and Engineering Aspects, 151: 147-166.

Lacher, C. and Smith, R.W., 2002. Sorption of Hg(II) by Potamogeton natans dead biomass. Minerals Engineering, 15: 187-191.

Leyva-Ramos, R., Rangel-Mendez, J.R., Mendoza-Barron, J., Fuentes-Rubio, L. and Guerrero-Coronado, R.M., 1997. Adsorption of cadmium(II) from aqueous solution onto activated carbon. Water Science and Technology, 35(7): 205-211.

Lodeiro, P., Cordero, B., Grille, Z., Herrero, R. and Sastre de Vicente, M.E., 2004. Physicochemical studies of Cadmium (II) biosorption by the invasive alga in Europe, Sargassum muticum. Biotechnology and Bioengineering, 88(2): 237247.

Nadal, A.M., Ariño, C., Esteban, M. and Casassas, E., 1991. Voltammetric study of Cadmium(II) ion in the presence of polysaccharides. Electroanalysis, 3: 309318.

Percival, E. and McDowell, R.H., 1967. Chemistry and enzymology of marine algal polysaccharides. Academic Press, London New York, xii, 219 pp.

Rey-Castro, C., Herrero, R. and Sastre de Vicente, M.E., 2004a. Gibbs-Donnan and specific ion interaction theory descriptions of the effect of ionic strength on proton dissociation of alginic acid. Journal of Electroanalytical Chemistry, 564: 223-230.

Rey-Castro, C., Herrero, R. and Sastre de Vicente, M.E., 2004b. Surface charge and permeable gel descriptions of the ionic strength influence on proton binding to seaweed biomass. Chemical Speciation and Bioavailability, 16(1-2): 61-69.

Rey-Castro, C., Lodeiro, P., Herrero, R. and Sastre de Vicente, M.E., 2003. Acid-base properties of brown seaweed biomass considered as a Donnan Gel. A model 
reflecting electrostatic effects and chemical heterogeneity. Environmental Science \& Technology, 37(22): 5159-5167.

Schiewer, S. and Volesky, B., 1997a. Ionic strength and electrostatic effects in biosorption of divalent metal ions and protons. Environmental Science \& Technology, 31(9): 2478-2485.

Schiewer, S. and Volesky, B., 1997b. Ionic strength and electrotatic effects in biosorption of protons. Environmental Science \& Technology, 31(7): 18631871.

Schiewer, S. and Volesky, B., 2000. Biosorption processes for heavy metal removal. In: D.R. Lovley (Editor), Environmental Microbe-Metal Interactions. ASM Press, Washington D.C., pp. 329-362.

Schiewer, S. and Wong, M.H., 2000. Ionic strength effects in biosorption of metals by marine algae. Chemosphere, 41: 271-282.

Vasudevan, P., Padmavathy, V. and Dhingra, S.C., 2003. Kinetics of biosorption of cadmium on Baker's yeast. Bioresource Technology, 89: 281-287.

Vázquez, G., González-Álvarez, J., Freire, S., López-Lorenzo, M. and Antorrena, G., 2002. Removal of cadmium and mercury ions from aqueous solution by sorption on treated Pinus pinaster bark: kinetics and isotherms. Bioresource Technology, 82: 247-251.

Volesky, B., 2001. Detoxification of metal-bearing effluents: biosorption for the next century. Hydrometallurgy, 59: 203-216.

Wase, J. and Forster, C.F., 1997. Biosorbents for metal ions. Taylor \& Francis, London, x, 238 pp. 